\title{
IMAGINATION IN THE CREATIVE SELF- EXPRESSION OF STUDENTS IN SECONDARY SCHOOL LITERATURE CLASSES
}

\author{
Daiga Celmina \\ Rigas Teikas Secondary School, Latvia
}

\begin{abstract}
The paper's aim is to make topical the role of imagination in thinking processes and learning cognition and in the creative self-expression of students in secondary school Literature classes. The paper summarizes theoretical pedagogical and psychological findings about imagination in cognitive activity and links them with the author's practical experience in the work of a secondary school Literature teacher. The research issue is how to stimulate imagination in secondary school students' cognitive activity during literature classes, thereby promoting their creative self-expression and self-experience. This issue is topical when contemplating the formation of a creative personality and a skilled, creative reader. The role of imagination is regarded from three viewpoints: the relation of imagination to the development of thinking; the role of imagination in creative self-expression and self-experience of students; creative exercises in secondary school literature classes as imagination stimulators. In the learning process related to artistic cognition, connection between scientific and artistically directed cognitive activity is relevant because the development of a free and creative personality requires linking of critical thinking, imagination and emotional attitudes, which in turn forms creative self-experience of students, the ability to use knowledge, skills and attitudes acquired in the learning process of diverse life situations. Creative problem tasks in Literature classes are one of the pedagogical means to encourage students to look for connections between different science fields, topics, facts, events, objects, phenomena, images and draw independent take-aways and conclusions, as well as encourage students to express themselves creatively. The research methods: literature analysis, content analysis, self-experience analysis, survey.
\end{abstract}

Keywords: cognition, creative exercises, imagination, literature studies, self-experience, self-expression.

\section{Introduction}

The year 2020 has brought changes in the learning process, due to the pandemic, learning takes place remotely in several class groups, therefore the role of many basic categories of pedagogy is becoming more important 
in the remote learning process. The tasks of the learning process in general are also becoming more relevant at this time of economic and social change. How to raise motivated, curious students who are ready to face the unpredictable tasks of tomorrow? The educational success is no longer mainly knowledge content reproduction but rather the practical application of knowledge in new situations. Therefore, it is necessary to stimulate curiosity, the ability to find connections between ideas, which requires knowledge not only in one, but between different areas (Fadel, Bialik, \& Trilling, 2017). Researchers of digital childhood admit that representatives of digital generation have less ability to imagine and fantasise; however, they have more developed skills to sort out information (Rubene, 2016). There is a need to unlock thinking potential of students and to develop their analytical skills, for them to be able to cope with tasks set by changing social environment and global challenges (Rubene, \& Svece, 2019, p. 406). Consequently, it is important to identify the basic categories of pedagogy and to trace their role in the modern education process where remote learning currently plays an important role. Thus, it is important to look both theoretically and practically at the imagination as the ability of creative thinking and the role of imagination in the cognitive learning activity in secondary school literature classes.

\section{The Relation of Imagination to Thinking Development}

According to T. Buzan, the brain has five major functions: receiving, storing, analysing, controlling, outputting: the brain outputs received information through thoughts, speech, drawing, movement, and all other forms of creativity. These processes are complex and are still being studied because the neural connections in the brain do not allow such a sharp separation of the functions of the brain cortexes. Further research has shown that "when people were encouraged to develop a mental area they had previously considered weak, this development, rather than detracting from other areas, seemed to produce a synergetic effect in which all areas of mental performance improved" (Buzan, 2008, p. 16).

T. Chernigovskaya indicates that, it is important, especially during remote learning, to organize cognitive activities in learning in such a way that the learning becomes a conscious process, that students develop open-mindedness, that knowledge and skills become a part of long-term memory which is related to imagination and the ability to form association chains. "If we lie down on the sofa for six months, we won't be able to stand up. It's the same with the brain: it has to work hard. Hard work is the key word. It must always be difficult for your brain. Read a book difficult for you, watch a film that you don't understand, or enjoy a performance where the director's message is unclear. To understand that, you will think 
a lot, read reviews, and look for information. The brain will be loaded with work and thus it will develop. You don't have to look for tips to improve your brain. The life itself is a tip" (Chernigovskaya, 2020).

L. Vygotsky studies the psychological development of a child from birth to adolescence. He focuses on the characterization of imagination in the studies of $20^{\text {th }}$ century psychologists (such as T. Ribot, W. Wundt, J. Piaget) who describe the objective basis of imaginary processes: the connection of imagination with experience, with past impressions and language. L. Vygotsky points out that the analysis of imaginary processes in its complex forms and the analysis of thinking processes in general show that: the development of both thinking and imagination processes in children is related to the development of language (speech); logical and imaginative thinking develop in parallel in close conjunction; when we observe the forms of imagination associated with creativity and focused on reality, we can see that the line between realistic thinking and imagination disappears and the imagination becomes an absolutely necessary moment of realistic thinking. Cognition of reality is not possible without imagination, without the ability to distance oneself from reality, from those specific impressions that form our notions of reality (Vygotsky, 2003, p. 651).

L. Vygotsky concludes that the most important difference between reproductive imagination and memory is that the imagination does not repeat certain preciously obtained impressions in the same connections and forms, but it builds new connections from these previously acquired impressions, resulting in a new, unprecedented image. New imaginative combinations arise from new constellations that are new relations between elements (Vygotsky, 2003, p. 638).

In the search for essence of imagination in philosophy, p. Ricoeur notes that imagination can be reproductive (imitative) and productive (creative). Imagination materialises through language, understanding of text and creation. Ricoeur emphasises the significance of reading, particularly of reading fiction, as it develops ability of "seeing as" and metaphorical thinking. "Seeing as" is linked to philosophical concept of language game, because it involves surprise of discovery (creation). Therefore, psycholinguistics could cross the line and link the sensual and emotional perception of image with the semantic and conceptual perception of image (Ricoeur, 2003, p. 252).

In the context of L. Vygotsky's research, it is significant to find that a very big step in the children's imagination development takes place in connection with the children's speech development. Thus, it can be concluded that the development of speech is correlated to the development of imagination. A child acquires the opportunity to express in language what does not coincide with the objects of direct reality or the perceptions of reality. The child can freely talk about their impressions. Vygotsky points out that 
it is important to focus in more detail on the emotional aspects of imagination development. Often, one or another scene in a child's imagination seems unrealistic from a rational point of view, but they are real from an emotional point of view (Vygotsky, 2003, p. 648). D. Siegel indicates that it is essential to study how and why personal feeling of world is so important for individual's health and relationships. And how can we respect this feeling in the learning process? (Siegel, 2017).

L. Vygotsky underlines that only in adolescence does a child comes to thinking in concepts. However, the ability to form concepts, the verbal expression of concepts and the application of concepts to processes do not all take place simultaneously in child's development. The process of transferring concepts is more difficult, i. e., extending the concept to other different things, when the separation and synthesis of features in concepts has to meet with other specific features and when they are given in other specific situations and proportions. The transitional character of adolescent thinking becomes especially evident when we observe and functionally research the adolescent's use of concepts not in a ready form, but in action, because it is only in function and use that the true nature of the concepts reveals itself. By studying a concept in action, we discover evidence of adolescent characteristics in their intellectual activity as a whole and also of their personality and world-view development. Given that transition from thought to concept and word is hard because learning cognition requires a complex way of conveying thought, adolescents sometimes complain about the imperfection of words, that it is not possible to express their thought into words (Vygotsky, 2002, p. 180).

L. Tateo indicates that "imagination is a fundamental psychological higher function that elaborates meaning by linguistic and iconic signs, related to memory" because with the help of imagination one reveals the hidden meaning of words, signs, text, subtext (Tateo, 2015, p. 3).

L. Tateo systematizes the features of imagination is :

- related to memory, to problem solving, playing a crucial role in the scientific thinking, art, and societal change as well as in education and promotion of wellbeing;

- not in opposition with rational thinking and reality" they complement each other, imagination is also fundamental to guide the future oriented behavior both at individual and collective levels;

- a phenomenon that cannot rely on laboratory experiments or on language-based methods such as interviews" because in the processes of imagination, reality is related to abstract associations, while associations and images are related to reality (Tateo, 2015, p. 2).

Thus, the imagination is a function of advanced thinking, which is related to both the linguistic and iconic sign aspects, related to memory, 
fantasy and intelligence. Imagination plays a key role in science, art, and in social and emotional attitudes, in relation to education and the well-being of society as a whole (Tateo, 2015, p. 1).

Imagination can appear in any of these five sensory modality types: it can be perceived visually, by hearing, movement, smell or taste. For most people, visual perception the strongest, thus imagination appears mostly in visual form. Over time, different imagination technique types have evolved, related to different individual representative perception types (visual type, auditory type, kinaesthetic type) (Ozolina Nucho, \& Vidnere, 2011).

Imagination is a self-programming tool. Adventures create feelings which condense in the imagination. In turn, the imagination creates feelings, and feelings lead to action. We form the imagination from our sensory impressions and perceptions, and these are the basic abstractions of our beginning. Imagination is the embodiment of spontaneous ideas which have the ability to point to new objects and connections by analogy (Vidnere, 2015, p.14).

Imagination is "an internal, private level of mental activity that is not accessible to an outside observer" it is real and its course and the consequences of the process are important. (Nucho, Vidnere, 2004, p. 129). Use of methods that stimulate imagination, for example, visual and verbal expression, develops problem-solving skills in everyday life, in the arts and research.

\section{Imagination in the Students' Creative Self-Expression}

Imagination is significant in students thinking development, as it enables linking experience with new information, plan actions, by imagining the outcome, and suggest hypothesis for one's researches.

A. Špona indicates that "self-experience is knowledge, skills, attitudes acquired and evaluated in life, which have become personally important values" and points out that creative self-experience is linked to the fact that the knowledge, skills and attitudes can be used in a variety of life situations and that the means of developing creative self-experience problem and research-based learning (Špona, 2006, p. 161).

Problem-based learning consists of the general cognitive process regularities, the ability to see contradictions in a problem, to reveal possibilities of resolving contradictions, which is related to creative thinking. It is important that students develop a desire to look for connections between facts, events, things, phenomena, they should be encouraged to make independent decisions. Self-experience gained in learning process is a great human value. Through cooperation everyone, be it a school or university student, teacher or teaching staff, gains self-experience, and that is the dialogical character of educational process (Špona, 2018, p. 19). 
E. Maslo reminds that attitudes towards learning change in late teens, leading to differences in learning. This particular age is a transition period in biopsychosocial development. The learning process has an impact on these processes, so it is important to take into account that at this age thinking becomes more critical, selective and independent, abstract and systematic, students like to generalize, looking for the principles and laws behind the facts. These students are aware of the connections of the world, they observe the world and make their own conclusions about it (2003, p.67). Learning is self-expression and self-realisation. If individuals do not have an opportunity to express themselves during the class, they do not know what to do in order to develop purposefully. Freedom means free will and self-realisation. Students will gain competence only through their own conclusions. We make conclusions by reasoning and by interaction between teachers and students (Špona, 2018).

$21^{\text {st }}$ century learning process is related to the evaluation of the relationship between teaching and learning. The teacher is encouraged to be more of a facilitator of learning than a disseminator of knowledge. It marks the transition to a process-oriented learning task that focuses on students' acquisition of knowledge and its application in action. It is a gradual transition from control of the learning process to students' self-assessment of their learning task. The main tasks of the learning process are aimed at promoting and guiding students' thinking and action attitudes, stimulating the interest of learning and facilitating thoughtful learning (Vidnere, Bogdanova, 2019).

J. Anspaks draws attention to the fact that one of the problems of art pedagogy theory and practice is:

- to supplement the understanding of the cognition peculiarities in the learning process;

- to discover the possibilities of the cognitive process in artistically oriented cognition action and creation;

- to study the conditions for the development of personal creative abilities in the process of artistic cognition. (Anspaks, 2004, p. 94)

Consequently, the discovery of the peculiarities of scientific and artistic cognition and their interaction in the development of one seamless, creative personality is very relevant in art pedagogy (Anspaks, 2004).

E. Husserl has studied how objectivity is reflected in subjective consciousness and he points out that it is important in learning cognitive activity to respect how an individual experiences, feels the world in his inner experience, because we have to deal with reality so far as it is perceived, imagined, observed, conceptually meant (Husserl, 2002, p. 166). This is in line with L. Vygotsky's view that the imagination should be seen as a complex form of individual mental brain activity, that combines several 
functions in their peculiar relationships. To describe such complex processes that go beyond the notion of function, the notion of psychological system which includes inter-functional connections and relationships could be used (Vygotsky, 2003).

Similarly, Heidegger connects imagination with both consciousness and emotion and points to the role of artwork, culture and cultural policy in general, because it can be said metaphorically that an artwork reveals the existence of the existing first of all and secondly, an artwork becomes an object of experience and, as a result, life becomes an expression of human life (Heiddeger, 1998, p. 158). Individuals cannot act creatively if their imagination is not being developed with emphasis on the link between imagination and its source - objective reality.

The Latvian education reform project School 2030 (Skola 2030) includes creativity in transversal competences which are critical thinking and problem solving, creativity and entrepreneurship and self-directed learning. Creativity in any education field is about nurturing freedom and creative thinking of students. Entrepreneurship is inconceivable without a person's self-confidence, daring, accepting a challenge, creating innovative solutions. Critical thinking requires attention and flexibility to take into account different points of view that differ from conventional thinking and evaluation models. Problem solving is precisely problem solving because existing patterns of action and behaviour are not effective, therefore new ones need to be created. In turn, self-directed learning involves the awareness and purposeful development of the students' individual abilities and interests. It is important to understand the nature of creativity and the difference between fostering creativity and drilling texts. As creativity is a complex and controversial phenomenon, its promotion in the learning process requires a special approach which differs from the classical understanding of learning as the acquisition of knowledge or skills (Briška, \& Kalēja-Gasparoviča, 2020).

S. Congram are the successors of C. G. Jung's ideas and they apply Jung' $s$ active imagination theory in their practice, where imagination is helping a person to discover deep aspects of their self. Jung associates active imagination with the deepest unconsciousness where images have a life of their own. In order to put this process of active imagination into practice, students were offered various creative exercises with elements of art, dance, poetry and masks. During the course of their research S. Congram concludes that imagination is essential in the personal cognition activity, self-expression and self-actualization. Imagination-enhancing activities can both raise and lower students' self-esteem, therefore it is important to inform students about the importance of the process, not about how to do the exercise right or wrong. Artistic learning takes place in relations between a person, 
nature and the society, it takes place through experience, through the body, offering a wide range of learning and gaining self-confidence. The teacher becomes a coordinator in this learning process, because one has to feel when to intervene, when to support, when to initiate a temporary break in order for the student to perform healthy self-reflection. Teachers' tasks are the following:

- develop imagination incentivizing exercises;

- create an appropriate learning environment;

- cooperate with students to build trust and support;

- respond to the needs of students, because it is difficult to plan this creative work in advance (Congram, 2008, p. 14).

\section{Creative Imagination Exercises in Secondary School Literature Learning}

There are several stages in solving creative problems: seeing, isolating, formulating a problem and finding a hypothesis (task solving idea), testing it, a verbal (written) presentation of the results obtained in the solution. Almost every step requires overcoming contradictions in the creative activity of performing literary tasks. There is no and cannot be only one correct solution to the creative problem in the study of literature, because it is related to the understanding of art, ethical aesthetic truths and values (Rudzìtis, 2000, p. 121).

Solving literary problems requires both creativity and experience of creative activity. Rudzitis points out that a problem arises here: can creative work be taught? And he himself gives the answer that students can be given guidelines for cognitive activity, demonstrated examples, explained situations; however, the main focus should be on fostering the development of relevant abilities (imagination included), while keeping in mind that they are formed only in appropriate artistically oriented cognitive activity. The task of the teacher is to purposefully manage the literature learning process to offer students creative exercises (Rudzìtis, 2000).

Imagination is not only a person's unique ability to see what is not directly seen or said, but also the basis of all inventions and innovations. Hence its value is immeasurable, it allows us to get to know and learn from the experiences of many people we have never met in life (Gotlieb, Jahner, Immordino-Yang, \& Kaufman, 2016). M. Kūle and R. Kūlis has pointed out in her research the positive role and the risks of technology in cognitive processes: The cultural values of the technological age change the perception of space and time, as well as human relationships which are formed faster and, unfortunately, become more superficial (Kūle, \& Kūlis, 2020, p. 419). 
The development of young people's imagination is related to their skills in the technological age to create alternative perspectives, as well as emotional attitudes. These imagination abilities manifest in the creative thinking process, offering a different approach to problem solving or organizing activities. Imagination fosters both a creative and critical attitude towards new learning content, fosters the ability to find connections between previously acquired and new knowledge, and offers new ways to use the newly acquired knowledge in the future. Students' school success and lifelong creativity are facilitated not only by the cognitive skills measured by Intellectual Quotient tests but by other cognitive and social-emotional attributes. Therefore, imagination is very important because it allows students to comprehensively, in the coexistence of part and whole, understand what they are learning. As a result, school-related exercises become more personal, more meaningful for students, more related to life and more connected to their future adulthood (Gotlieb, Jahner, Immordino-Yang, \& Kaufman, 2016).

Research in pedagogy and psychology highlights the role of imagination in thinking processes, as well as the interrelationships between the development of imagination and language (speech), indicating that in adolescence conceptual thinking is developed, concepts being the basis of the most complex connections and conclusions. Initiated by an emotional impulse, the imagination arranges the facts of an individual's experience in a new order. This arrangement appears as a fantasy image, an idea, a conception. Then the person understands and evaluates the new idea. If it is found to be significant, a decision is made to implement it (Briška, \& Kalēja-Gasparoviča, 2020, p. 8).

The main important thing to understand today is that information has no value without people. There must always be someone who can interpret it. "The same word, the same concept, the same scenario mean absolutely different things depending on who speaks, who listens, what is shown, what education those people have, what was said before that, and why that was said" (Chernigovskaya, 2020).

In learning cognitive activity, it is important to offer the opportunity to look at the results to be achieved and the issues from different points of view. Creativity involves new approaches and alternatives, including the significant use of challenge, chance and provocation as creative impulses in the thinking process. Independence, responsibility, initiative and creativity are related to interdisciplinarity, cooperation and cultural education in the learning process, where understanding the meaning of the text read, use of reasoning in reading and writing, imagination, recognizing topicality, ability to learn independently are all essential. It is openness to new experiences that, owing to cooperation, directs students towards their subjective search for meaning. 


\section{Methodology and Results}

The following methods are used in the research: literature analysis, content analysis, self-experience analysis, survey.

In the $2019 / 2020$ school year, as part of remote learning, $11^{\text {th }}$ grade students were offered a creative visualisation exercise after reading Part One of the J. W. von Goethe's play Faust. This was one of several exercises given at the closing of a theme. After the exercise was done, a content analysis was performed on students' work and their self-analysis, a survey was organized and a survey data analysis was performed. The exercise was based on stimulation of imagination: visualization by symbols and written explanation of thoughts. The criteria for assessment were the uniqueness of idea, understanding of the overt meaning and hidden meaning of the text, and use of images, metaphors and symbols.

The exercise given to students was the following: after having read the Goethe's Faust, using a white paper sheet and a black line, they had to:

1. create a visualization of the play's idea, revealing something that they had found significant about the play subtext, its problems discussed, the relationships between the characters;

2. use play-related characters and symbols in the visualisation;

3. make topical some significant quote from the play text;

4. explain their idea in a written comment.

The completed exercises were handed in via Microsoft Teams platform in the form of photographs of the creative visualisations and a Word document with commentary on their work and a table where all main characters of the play and their interrelationships were described. In order to present an illustrative example, four of the visualisation works have been added to the present article (Image 1, 2, 3, \& 4). Students have consented to the use of their works in the publication provided the authors of works remain anonymous.

Each work is accompanied by a descriptive commentary on the idea contained in the drawing. For example, one student writes: "Goethe's play Faust is a story of a conflict of soul between good and evil. The question is - which is stronger. Because throughout lifetime, we solve these problems by constantly making choices, growing in spirit. The growth leads to breaking of unwanted ties and fight for freedom. The scissors in my drawing symbolize the human reason that cuts ties with wrongful choices. It happens sooner or later - everyone ventually gets on the right track and everyone has the right to make mistakes along the search for the truth" (Visualisation 1). 


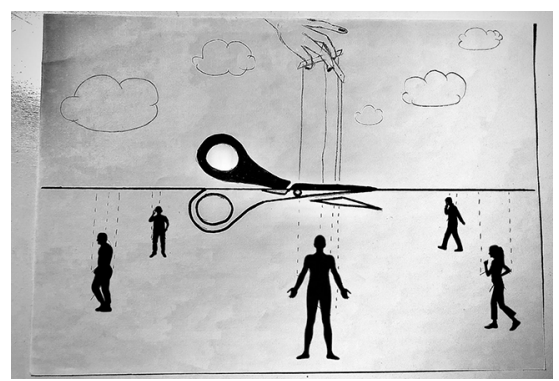

Image 1. Visualisation 1

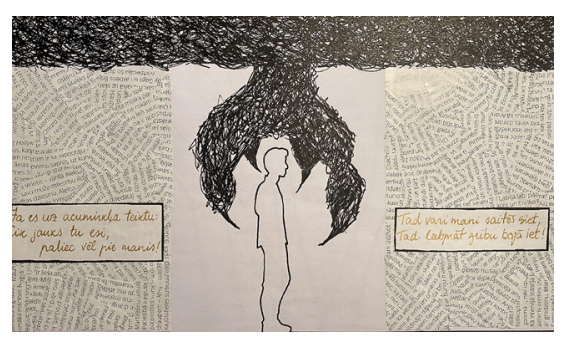

Image 2. Visualisation 2

After completing the exercise, the students participated in a Google survey with the following questions:

- Did the creative exercise help to better understand the content of the literary work? (see Fig. 1)

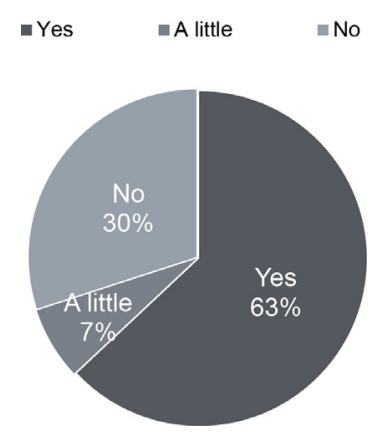

Figure 1. Question 1. Did the exercise help you to better understand the content of the literary work? 83 responses

- Did this exercise encourage you to think about issues that are relevant to you and society? (see Fig. 2)

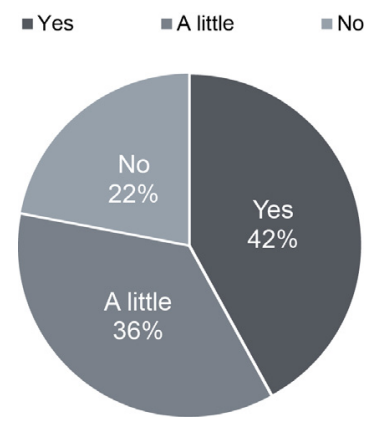

Figure 2. Question 2. Did the exercise encourage you to think about issues that are relevant to you and society? 83 responses 
- Describe what you found valuable in this exercise!

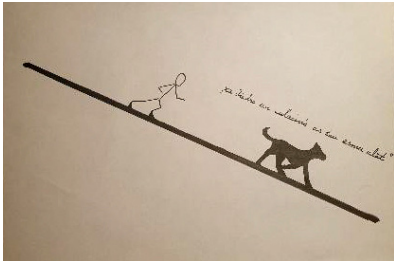

Image 3. Visualisation 3

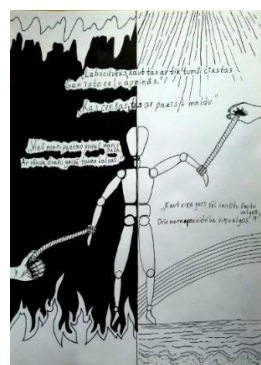

Image 4. Visualisation 4

- What are your suggestions for more successful work in literature classes?

A total of 83 secondary school students (16 to 18 years of age) participated in the survey, having performed a creative visualization exercise during the study process after having read the literary work.

In this study, pupils' freely expressed self-evaluation responses were categorised into two groups: positive evaluation and critical evaluation. Then, performing a qualitative content analysis, the conclusions are summarized in the table "Strengths and weaknesses of creative visualization tasks". The survey collected the following positive student responses: "I enjoyed the task execution process"; "I had to think outside the box in order to complete the exercise more successfully"; "Developing my imagination will make it easier to read and understand this type of work next time"; "I would like to read more books to have more experience and skills to be able to imagine, visualize and understand how to use different signs and symbols"; "The exercise helped me to better understand the text, as I had found Faust was difficult to read. I like that you can not only read, but also comprehend more through drawings and thus train your imagination"; "I had the opportunity to think about the symbolic meaning of the characters. It is an in-depth analysis of the text and its connection with our visual work"; "The value of the exercise is the ability to compare plays and modern values"; "I like to discuss and analyse both books and creative works together"; "The conditions of the exercise about the white page and the black line were interesting. This made me go deep into the text and find the hidden symbols"; "The instructions were very broad, so the possibilities of execution were endless. I like to listen to the teacher's thoughts on stories and plays"; "It is worth looking at how others portray and understand the same quote. I like reading together and discussing it after"; "This exercise develops imagination and reveals how others understand the same book"; "The exercise allowed me to think irrationally and made me go deeper into 
the text. Valuably, this visualization is a kind of text analysis that makes you think differently and look at the text from a different point of view"; "The exercise encouraged me to go deeper into the text, understand it fantasise about its content"; "In my opinion, it was valuable to draw, think and develop my own unique idea that stimulated my imagination. It is rare to do something similar on a daily basis, so I thought it was valuable".

There were also critical and negative comments in student self-assessments: "Interesting pastime but this won't be useful to me in the future"; "We should read less because I believe we already read a lot this year"; "Many are not really interested in all this, let's be honest. Personally, I really like to listen when you, Teacher, talk about a literary work or a show play, a film. Then I become interested in these works, there is a greater desire to read them"; "It is difficult for me to perform such Literature exercisess"; "I would suggest slowing down"; "For me, this exercise did not stimulate my imagination, only irritated my nerves. I believe that it is always better to get information by doing practical things"; "I would like less work, more listening"; "I would enjoy literature classes more if I could choose for myself what to read".

During remote classes for this particular exercise related to experience students used traditional visualization methods (drawing or collage) and submitted their works as photographs. However, students like to use graphic design software as well; therefore, they should be given a chance to use their digital skills which have been obtained during and after classes.

The results are summarized in the following table Strengths and Weaknesses (Table 1).

Table 1. Strengths and Weaknesses of the Creative Imagination Tasks

\begin{tabular}{|l|l|}
\hline Strengths & Weaknesses \\
\hline - Develops creativity, stimulates the & - Relevancy of the texts; \\
imagination; & - The texts are not always \\
- Helps reveal text content, subtext; & $\begin{array}{l}\text { interesting from the student' point } \\
\text { of view; }\end{array}$ \\
- Relation to philosophy and other science & - Too little time to complete the \\
fields; & exercise; \\
- Connection s of the text with emotions and & - Sometimes in the oral evaluation \\
values; & of the creative exercise \\
- Allows to leave one's comfort zone; & performance, performance and \\
- Creative self-expression; & opinion of just a few students take \\
- Images and symbols help better understand & the stage; \\
the literary work; & - Visualization exercises should be \\
- An opportunity to share ideas and be inspired & varied to avoid repetition; \\
when orally presenting comments; & - The role of creative exercise in \\
- During the oral analysis, a dialogue is formed & cognitive learning needs to be \\
with the teacher and classmates; & more clarified and justified; \\
- Mutual cooperation and support, taking into & - Appreciate creative thinking and \\
account the needs of students; & achievement of each student. \\
- Develops deep reading skills. & \multicolumn{2}{|l}{} \\
\hline
\end{tabular}


Advantages and disadvantages of the creative exercise identified by students match the theoretical conclusions, namely, creative imagination exercises in literature studies enable creative self-expression through visualization and language - justification of one's idea. Such exercises give an opportunity to interact with classmates and teacher, and they make students think about the process of thinking and deep reading thus uncovering the interdisciplinarity of the exercise. The risks remind that the chosen literary work should be topical for students, the purpose of the exercise should be well-grounded, appropriate time for completion of the exercise should be given, and performance of each student should be valued.

\section{Conclusions}

Imagination is a component of learning cognitive activity that promotes forms of thinking: analysis, synthesis, generalization, and creativity. Imagination does not repeat past impressions in the same connections and forms, it builds new connections from the previously acquired impressions, resulting in a new, never-seen-before image. New imagination combinations arise from new relationships between elements.

Research in pedagogy and psychology has also highlighted the role of imagination in thinking processes, as well as the interrelationships between the development of imagination and language (speech), indicating that in adolescence thinking continues to develop in concepts that are the basis of the most complex connections and conclusions.

Creative exercises in literature classes are one of the pedagogical tools to incentivise students to look for connections between different science fields, topics, facts, events, objects, phenomena, images and to draw independent conclusions, realisations, as well as to encourage students to express themselves creatively. Stimulation of imagination is one of the goals of literature studies.

\section{References}

Anspaks, J. (2004). Mākslas pedagoǵija. 1. Daļa [Art pedagogy. Part I]. RaKa.

Briška, I., \& Kalēja-Gasparoviča, D. (2020). Skolēnu radošuma sekmēšana un vērtēšana [Promoting and evaluating students' creativity]. LU.

Buzan, T. (2008). Efektīvas mācīšanās rokasgrāmata [The Buzan study skills handbook] (I. Teibe, Transl.). Jāṇa Rozes apgāds. (Original work published 2007).

Chernigovskaya, T. (2020, April 22). Digitalisation and Humanity: Neurolinguist on the features of living in the digital world. (N. Gavrilov, Transl.) Global Women Media. Retrieved from: https://cutt.ly/Yj7koc8

Congram, S. (2008). Arts-informed learning in manager-leader development. In R. Jones, A. Clarkson, S. Congram, \& N. Stratton (Eds.), Education and imagination: post-Jungian perspectives (pp. 160-177). Routledge. 
Fadel, C., Bialik M., \& Trilling, B. (2017). Četru dimensiju izglītïba [Four-dimensional education: The Competencies learners] (Lielvārds, Transl.). Lielvārds. (Original work published 2015).

Gotlieb, R., Jahner, E., Immordino-Yang, M., \& Kaufman, S. (2016). How socialemotional imagination facilitates deep learning and creativity in the classroom. In R. Beghetto \& J. Kaufman (Eds.), Nurturing Creativity in the Classroom (pp. 308-336). Cambridge University Press.

Heidegger, M. (1998). Malkascel̦i [Holzwege]. Kontinents. (Original work published 1980).

Husserl, E. (2002). Fenomenologiija [Die idee der phänomenologie] (R. Kūlis \& A. Dāboliņ̌s, Transl.) LU Filozofijas un sociologijijas institūta apgāds. (Original work published 1973).

Kūle, M., \& Kūlis, R. (2020). Filosofija [Philosophy]. Zvaigzne ABC. (Original work published 1996).

Maslo, E. (2003). Mācīšanās spēju pilnveide [Improving learning abilities]. RaKa.

Ozoliṇa Nucho, A., \& Vidnere, M. (2004). Stress: tā pārvarēšana un profilakse [Stress: Management and prevention]. Apgāds Biznesa Partneri.

Ozoliṇa Nucho, A., \& Vidnere, M. (2011). Mākslas terapija: psihokibernētiskais modelis [Art Therapy: Psycho-Cybernetic Model]. RaKa.

Ricoeur, p. (2003). The Rule of metaphor ( $3^{\text {rd }}$ edition). Routledge Classics. (Original work published 1975).

Rubene, Z. (2015). Vai viegli būt beernam? [Is it easy to be a child?]. The Rights, Equality and Citizenship Programme. Retrieved from: https://centrsdardedze.lv/data/ konference/Zanda_Rubene_I_sesija.pdf

Rubene, Z., \& Svece, A. (2019). Development of critical thinking in education of Latvia: Situation analysis and optimisation strategy. In L. Daniela (Eds), Innovations, Technologies and Research in Education (pp. 405-421). University of Latvia Press.

Rudzītis, J. (2000). Literatūras mācības skolā [Literature studies at school]. RaKa.

Sīgels, D. (2017). Prāts. Cilvēka būtỉbas meklējumos [Mind your brain]. Jumava.

Skola 2030. [School 2030]. (2019). Retrieved May 20, 2020. https://www.skola2030.lv/

Špona, A. (2006). Audzināšanas process teorijā un praksē [Upbringing process in theory and practice]. RaKa.

Špona, A. (2018). Jauns pedagogijas zinātnes priekšmets. [A new subject of pedagogical science]. News of the Latvia Academy of Sciences (pp. 15-22). LZA.

Tateo, L. (2015). Just an illusion? Imagination as higher mental function. Journal of Psychology \& Psychotherapy 5(6), 1. https://doi.10.4172/2161-0487.1000216

Vidnere, M. (2015). Iztēle: psihologíija un terapija [Imagination: Psychology and therapy]. RaKa.

Vidnere, M., \& Bogdanova, T. (2019). Skolotāja profesionālās identitātes komponents "Profesionālās zināšanas" [Teacher professional identity component "Professional knowledge"]. In A. Šteinberga (Eds.), Skolotāja profesionālā identitāte. [Teacher's Professional Identity] (pp. 74-79). RTU Izdevniecība.

Vygotsky, L. (2002). Domāšana un runa [Thinking and speech]. Madonas tipogrāfija.

Vygotsky, L. (2003). Psihologija razvitija cheloveka [Psychology of human development]. Eksmo. 